\title{
Assessment of Water Quality and Identification of Pollution Risk Locations in Tiaoxi River (Taihu Watershed), China
}

\author{
Kiran Kumar Vadde ${ }^{1}$, Jianjun Wang ${ }^{2}$, Long Cao ${ }^{1,3}$, Tianma Yuan ${ }^{1}$, Alan J. McCarthy ${ }^{4}$ and \\ Raju Sekar ${ }^{1, *(1)}$ \\ 1 Department of Biological Sciences, Xi'an Jiaotong-Liverpool University, Suzhou 215123, China; \\ Kumar.Kiran@xjtlu.edu.cn (K.K.V.); longcao@ips.ac.cn (L.C.); Tianma.Yuan@xjtlu.edu.cn (T.Y.) \\ 2 Nanjing Institute of Geography and Limnology, Chinese Academy of Sciences, Nanjing 210008, China; \\ jjwang@niglas.ac.cn \\ 3 Human Parasite Molecular and Cell Biology Unit, The Institute Pasteur of Shanghai, Chinese Academy of \\ Sciences, Shanghai 200031, China \\ 4 Microbiology Research Group, Institute of Integrative Biology, University of Liverpool, Liverpool L69 7ZB, \\ UK; aj55m@liverpool.ac.uk \\ * Correspondence: Sekar.Raju@xjtlu.edu.cn; Tel.: +86-512-8816-1656
}

Received: 21 August 2017; Accepted: 6 February 2018; Published: 10 February 2018

\begin{abstract}
Taihu Lake is the third largest freshwater lake in China and serves as a drinking water source for $\sim 30$ million residents. Tiaoxi River is one of the main rivers connected to this lake and contributes $>60 \%$ of the source water. Taihu Lake has been facing various environmental issues; therefore, it is important to study the water quality of its inflow rivers. This study aimed to evaluate the physico-chemical and microbiological characteristics of Tiaoxi River and to determine the spatial and seasonal variations in the water quality. Water samples were collected from 25 locations across the Tiaoxi River in three seasons in 2014-2015. Fourteen water quality parameters including multiple nutrients and indicator bacteria were assessed, and the data analyzed by multivariate statistical analyses. The physico-chemical analysis showed high levels $(>1 \mathrm{mg} / \mathrm{L})$ of total nitrogen (TN) in all locations for all seasons. Total phosphorus (TP), nitrite- $\mathrm{N}\left(\mathrm{NO}_{2}-\mathrm{N}\right)$, and ammonium-N $\left(\mathrm{NH}_{4}-\mathrm{N}\right)$ exceeded the acceptable limits in some locations and fecal coliform counts were high ( $>250 \mathrm{CFU} / 100 \mathrm{~mL}$ ) in 15 locations. Hierarchical cluster analysis showed that the sampling sites could be grouped into three clusters based on water quality, which were categorized as low, moderate, and high pollution areas. Principal component analysis (PCA) applied to the entire dataset identified four principal components which explained $83 \%$ of the variation; $\mathrm{pH}$, conductivity, $\mathrm{TP}$, and $\mathrm{NO}_{3}-\mathrm{N}$ were found to be the key parameters responsible for variations in water quality. The overall results indicated that some of the sampling locations in the Tiaoxi River are heavily contaminated with pollutants from various sources which can be correlated with land use patterns and anthropogenic activities.
\end{abstract}

Keywords: Tiaoxi River; Taihu watershed; water quality; pollution; multivariate analysis

\section{Introduction}

Surface water pollution remains a major problem worldwide, caused by both natural processes and anthropogenic activities [1]. Evaluation of surface water quality in drinking water sources is important as they can be one of the main pathways for the dissemination of toxic chemicals and pathogenic microorganisms [2,3]. Identifying the source(s) of contamination and developing appropriate management strategies is essential to minimizing potential public health risks [4]. The surface water quality in a region can be affected by both point and nonpoint sources of pollution [5]. 
Point source (PS) pollution occurs from a single identifiable source such as effluents from industries and wastewater treatment plants [6], whereas nonpoint sources (NPS) include runoff associated with a particular land use pattern such as urban (e.g., storm water, sewage overflows), agriculture (e.g., fertilizers, pesticides, animal manure), or forestry land uses [7]. Entry of these sources into water can represent the improper discharge of toxic chemicals and pathogenic microorganisms; therefore, water quality monitoring and sanitary risk identification are essential to protect the population from waterborne diseases and to develop appropriate preventive measures. Since environmental systems like rivers and lakes are affected by multiple sources, it is important to understand the spatial and temporal variations in physico-chemical and microbiological parameters for assessment and management [8]. However, assessing multiple water quality parameters generates large and complex datasets and multivariate statistical techniques are required to interpret the results [9-11]. Multivariate techniques likes cluster analysis (CA) and principal component analysis (PCA), have been successfully applied to better understand the water quality and ecological status of studied systems [12,13]. In addition to assessing the water quality, multivariate techniques have several applications such as the identification of possible factors/sources that influence water systems [14,15], data reduction [16,17], spatial and temporal variations [14], and grouping of sampling sites [18].

Taihu Lake is the third largest freshwater lake in China, located in southeast Jiangsu province and the Yangtze River basin [19], one of the most industrialized regions, where this lake serves multiple functions as a drinking water source and flood protection, and for fisheries, tourism, and transportation [20]. Pollution of water bodies is a serious concern in areas experiencing rapid urbanization. Rapid industrial development coupled with an increase in the population of the Taihu watershed has resulted in declining water quality and ecosystem health [19]. Increased anthropogenic activities combined with existing land use practices can increase pollutant loadings, such as nutrients and microbes, into water bodies that can affect public health [4]. On the other hand, rainfall events can further accelerate pollutant loadings due to entry of storm water runoff from urban areas, as well as from agricultural areas due to common practices such as manure use as fertilizers and livestock grazing near the water bodies [21]. Although the entry of pathogenic organisms is a major concern, nutrient loading can cause enrichment of water resources resulting in eutrophication [4]. It has been reported that inflow rivers are the major contributors to eutrophication and algal blooming in Taihu Lake [22,23]. At present, Taihu Lake is connected to more than 200 rivers [20]; water from tributaries enters the lake from the west side and goes out to rivers in the eastern side, primarily through Taihu Bay [24]. Tiaoxi River contributes approximately $60 \%$ of the total source water for Taihu Lake through 13 principal inflow rivers $[25,26]$. Previous reports showed that pollution from inflow rivers in a watershed can contribute to severe ecological and sanitary problems [13,27]. Therefore, it is important to assess the water quality of connecting rivers (such as Tiaoxi River) to prevent the entry of polluted waters and provide effective management of Taihu Lake's water quality. Recent reports showed that Tiaoxi River is heavily contaminated with pollution from multiple sources such as farmland, domestic sewage, and industry, which consequently impacts Taihu Lake water quality [28,29]. Studies focusing on detailed water quality analysis of Tiaoxi River or identification of pollution hotspots are limited [25,30,31]. Liu et al. [25] studied the size distribution and composition of phosphate in the East Tiaoxi River and Tang et al. [30] investigated estrogen pollution in the Tiaoxi River by chemical analysis and bioassays. Recently, Zheng et al. [31] studied the profiling of antibiotic resistance genes (ARGs) in water samples collected from different catchment areas in East Tiaoxi River, analyzed some water quality parameters-chemical oxygen demand (COD), TN, TP, and $\mathrm{NH}_{3}-\mathrm{N}$ and correlated them with ARGs and pathogenic bacteria. The main objective of the study reported here was to provide a more comprehensive assessment of the Tiaoxi River (east, west, and combined river) water quality and identify pollution hotspots based on physico-chemical and microbiological data through the application of multivariate statistical approaches. The results obtained in this study will be useful to identify pollution hotspots within the river for further monitoring and better management. Since 
increasing urbanization and its impact on water bodies is a serious problem worldwide, the results reported here will be of general interest and relevance.

\section{Materials and Methods}

\subsection{Study Area}

This study was carried out in the Tiaoxi River, which is one of the major rivers connected to Taihu Lake. The main stream of the Tiaoxi River is $158 \mathrm{~km}$ in length, comprising East and West Tiaoxi Rivers. The annual inflow of Tiaoxi River to Taihu Lake is 2.7 billion $\mathrm{m}^{3}$, which is approximately $60 \%$ of the total source water input of the lake [25]. Furthermore, it serves as a drinking water source and also supplies water for agricultural and industrial purposes for many cities located in northern Zhejiang Province, China [30]. Upstream, the river flows through agricultural areas, while the downstream part flows within the urban cities of northern Zhejiang Province and is subject to industrial inputs. The river collects waters from a population of approximately one million inhabitants, primarily located in moderately sized cities such as Huzhou along the river stream [26].

\subsection{Sampling Locations and Sample Collection}

Twenty-five sampling locations were selected for this study covering domestic, agricultural, and industrial areas. The land use patterns of areas close to the sampling locations are shown in Table 1.

Table 1. Description of sampling locations along with coordinates and corresponding land use types.

\begin{tabular}{|c|c|c|c|}
\hline \multirow{2}{*}{$\begin{array}{l}\text { Sampling } \\
\text { Location }\end{array}$} & \multirow{2}{*}{ Description of Location and Land Use Types } & \multicolumn{2}{|c|}{ Coordinates } \\
\hline & & Latitude & Longitude \\
\hline 1 & $\begin{array}{l}\text { Taihu Lake and Tiaoxi River junction; } 1 \text { km inside the Taihu Lake; } \\
\text { Aquaculture/fishing area. }\end{array}$ & $\mathrm{N} 30^{\circ} 57^{\prime} 3.15^{\prime \prime}$ & $\mathrm{E} 120^{\circ} 07^{\prime} 42.64^{\prime \prime}$ \\
\hline 2 & Suburban area with aquaculture and fish handling/processing area. & $\mathrm{N} 30^{\circ} 56^{\prime} 25.30^{\prime \prime}$ & $\mathrm{E} 120^{\circ} 07^{\prime} 35.72^{\prime \prime}$ \\
\hline 3 & Fishermen's village; People live on boats stationed at this location. & $\mathrm{N} 30^{\circ} 55^{\prime} 57.65^{\prime \prime}$ & $\mathrm{E} 120^{\circ} 07^{\prime} 37.27^{\prime \prime}$ \\
\hline 4 & $\begin{array}{l}\text { Suburban area with residential apartments, businesses, and parks; } \\
\text { East and West Tiaoxi River junction near south Taihu bridge. }\end{array}$ & $\mathrm{N} 30^{\circ} 53^{\prime} 50.96^{\prime \prime}$ & $\mathrm{E} 120^{\circ} 06^{\prime} 0.95^{\prime \prime}$ \\
\hline 5 & $\begin{array}{l}\text { Urban area with construction sites and various factories; Heavy } \\
\text { ferry transportation was noticed in this area. }\end{array}$ & $\mathrm{N} 30^{\circ} 53^{\prime} 19.40^{\prime \prime}$ & $\mathrm{E} 120^{\circ} 03^{\prime} 18.16^{\prime \prime}$ \\
\hline 6 & $\begin{array}{l}\text { Suburban and industrial area with various factories; West Tiaoxi } \\
\text { River and Changxing River junction. }\end{array}$ & $\mathrm{N} 30^{\circ} 52^{\prime} 55.15^{\prime \prime}$ & $\mathrm{E} 120^{\circ} 0^{\prime} 58.87^{\prime \prime}$ \\
\hline 7 & $\begin{array}{l}\text { Residential, farming, and small industrial area close to a village; } \\
\text { Various farm animals in small scale were noticed at the river bank. }\end{array}$ & N30 $53^{\prime} 14.16^{\prime \prime}$ & $\mathrm{E} 119^{\circ} 58^{\prime} 38.58^{\prime \prime}$ \\
\hline 8 & $\begin{array}{l}\text { Close to a town with businesses and residences; Ferry / boat } \\
\text { docking area. }\end{array}$ & $\mathrm{N} 30^{\circ} 53^{\prime} 1.82^{\prime \prime}$ & $\mathrm{E} 119^{\circ} 58^{\prime} 48.08^{\prime \prime}$ \\
\hline 9 & Rural agricultural area with sparse residential apartments. & $\mathrm{N} 30^{\circ} 52^{\prime} 43.41^{\prime \prime}$ & $\mathrm{E} 119^{\circ} 56^{\prime} 43.37^{\prime \prime}$ \\
\hline 10 & $\begin{array}{l}\text { Rural agriculture area with few industries (e.g., shipping industries } \\
\text { and oil station); Heavy ferry transportation was noticed in this area. }\end{array}$ & $\mathrm{N} 30^{\circ} 52^{\prime} 21.55^{\prime \prime}$ & $\mathrm{E} 119^{\circ} 53^{\prime} 55.85^{\prime \prime}$ \\
\hline 11 & $\begin{array}{l}\text { Rural with high number of residential apartments; Heavy ferry } \\
\text { transportation was noticed in this area. }\end{array}$ & N30 $52^{\prime} 8.11^{\prime \prime}$ & $\mathrm{E} 119^{\circ} 52^{\prime} 15.52^{\prime \prime}$ \\
\hline 12 & $\begin{array}{l}\text { Urban area with businesses (e.g., many shopping malls) and } \\
\text { residential apartments; Tourist boats docked close to this location. }\end{array}$ & N30 $52^{\prime} 54.56^{\prime \prime}$ & E120 $06^{\prime} 1.47^{\prime \prime}$ \\
\hline 13 & $\begin{array}{l}\text { Urban area with residential apartments and construction sites; } \\
\text { Second junction between West and East Tiaoxi River. }\end{array}$ & N30 $51^{\prime} 56.74^{\prime \prime}$ & $\mathrm{E} 120^{\circ} 04^{\prime} 25.11^{\prime \prime}$ \\
\hline 14 & $\begin{array}{l}\text { Suburban area with construction sites, residential apartments, and } \\
\text { businesses; Ferry docking (large scale) area. }\end{array}$ & $\mathrm{N} 30^{\circ} 50^{\prime} 53.74^{\prime \prime}$ & $\mathrm{E} 120^{\circ} 05^{\prime} 38.57^{\prime \prime}$ \\
\hline 15 & $\begin{array}{l}\text { Suburban area with residential apartments and businesses; Junction } \\
\text { between East Tiaoxi River and a small river which connects to Taihu } \\
\text { Lake; Sampled close to ferry docking (large scale) area. }\end{array}$ & N30 $50^{\prime} 59.27^{\prime \prime}$ & $\mathrm{E} 120^{\circ} 06^{\prime} 21.50^{\prime \prime}$ \\
\hline 16 & $\begin{array}{l}\text { Suburban and residential/business area; Junction between the main } \\
\text { river and a canal which connects to Taihu Lake. }\end{array}$ & N30 $51^{\prime} 27.75^{\prime \prime}$ & $\mathrm{E} 120^{\circ} 07^{\prime} 32.13^{\prime \prime}$ \\
\hline 17 & $\begin{array}{l}\text { Suburban and sparse residential area; Sampled at third junction } \\
\text { between West and East Tiaoxi River. }\end{array}$ & $\mathrm{N} 30^{\circ} 52^{\prime} 40.51^{\prime \prime}$ & $\mathrm{E} 120^{\circ} 01^{\prime} 58.88^{\prime \prime}$ \\
\hline
\end{tabular}


Table 1. Cont.

\begin{tabular}{|c|c|c|c|}
\hline \multirow{2}{*}{$\begin{array}{l}\text { Sampling } \\
\text { Location }\end{array}$} & \multirow{2}{*}{ Description of Location and Land Use Types } & \multicolumn{2}{|c|}{ Coordinates } \\
\hline & & Latitude & Longitude \\
\hline 18 & $\begin{array}{l}\text { Suburban and industrial area; Sampled in the junction of } \\
\text { Changxing and Tiaoxi River; Sampled near ferry docking station. }\end{array}$ & $\mathrm{N} 30^{\circ} 53^{\prime} 11.17^{\prime \prime}$ & $\mathrm{E} 120^{\circ} 0^{\prime} 52.95^{\prime \prime}$ \\
\hline 19 & Rural/village, sparse residential and industrial area. & $\mathrm{N} 30^{\circ} 54^{\prime} 2.88^{\prime \prime}$ & $\mathrm{E} 119^{\circ} 58^{\prime} 42.16^{\prime \prime}$ \\
\hline 20 & Rural/village and sparse residential/industrial area. & $\mathrm{N} 30^{\circ} 54^{\prime} 33.91^{\prime \prime}$ & $\mathrm{E} 119^{\circ} 57^{\prime} 31.34^{\prime \prime}$ \\
\hline 21 & Rural/village, residential and sparse industrial area. & $\mathrm{N} 30^{\circ} 55^{\prime} 52.05^{\prime \prime}$ & $\mathrm{E} 119^{\circ} 55^{\prime} 9.61^{\prime \prime}$ \\
\hline 22 & $\begin{array}{l}\text { Rural/village and industrial area; Heavy ferry transportation; } \\
\text { Sampled close to a factory and ferry docking station. }\end{array}$ & $\mathrm{N} 30^{\circ} 57^{\prime} 45.22^{\prime \prime}$ & $\mathrm{E} 119^{\circ} 55^{\prime} 19.98^{\prime \prime}$ \\
\hline 23 & $\begin{array}{l}\text { Rural/village area; Sampled in a small canal which connects to } \\
\text { Taihu Lake. }\end{array}$ & $\mathrm{N} 30^{\circ} 55^{\prime} 53.87^{\prime \prime}$ & $\mathrm{E} 120^{\circ} 11^{\prime} 35.48^{\prime \prime}$ \\
\hline 24 & Rural/village and sparse residential /industrial area. & $\mathrm{N} 30^{\circ} 51^{\prime} 0.12^{\prime \prime}$ & $\mathrm{E} 119^{\circ} 51^{\prime} 28.68^{\prime \prime}$ \\
\hline 25 & $\begin{array}{l}\text { Suburban area with businesses and industries; Many small rivers } \\
\text { branch off from East Tiaoxi River. }\end{array}$ & $\mathrm{N} 30^{\circ} 50^{\prime} 45.36^{\prime \prime}$ & $\mathrm{E} 120^{\circ} 08^{\prime} 21.54^{\prime \prime}$ \\
\hline
\end{tabular}

Surface water samples were collected along $100 \mathrm{~km}$ in the main streams of East and West Tiaoxi Rivers and also from Tiaoxi River junctions with other tributaries (Figure 1) in autumn 2014, and winter and summer 2015. Water samples were collected in sterile $5 \mathrm{~L}$ polypropylene containers and kept at ambient temperature until they were brought to the laboratory. The water samples were processed within $24 \mathrm{~h}$ of collection. Due to unforeseen circumstances, it was not possible to collect samples from a few locations in one or more seasons.
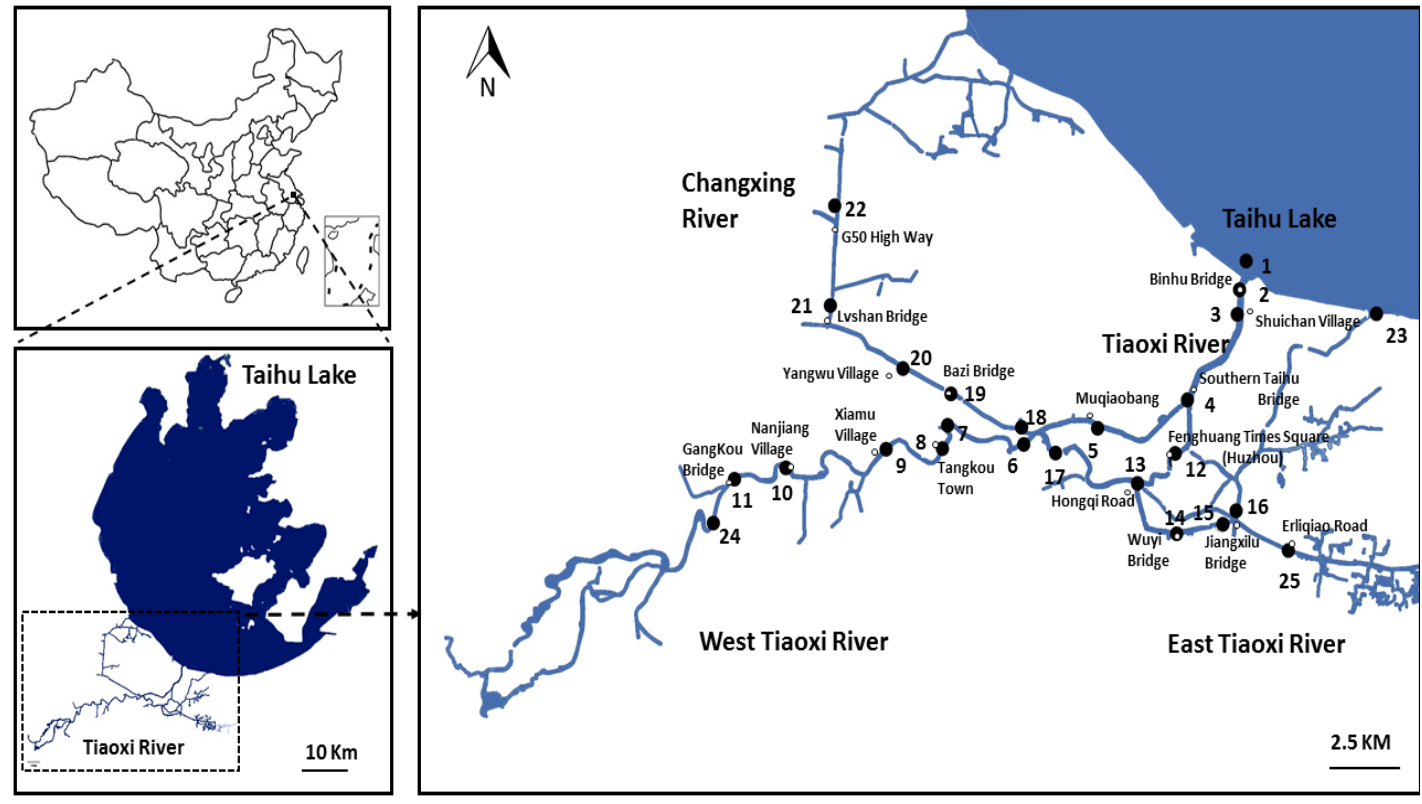

Figure 1. Map of the study area with sampling locations selected for surface water sampling in Tiaoxi River Basin.

\subsection{Physico-Chemical Parameters}

In China, the surface water quality is regulated by the Ministry of Environmental Protection (MEP) of People's Republic of China (PRC) and quality standards have been set for surface water [32]. Based on MEP standards, surface water bodies in China are classified into five categories based on their utilization and protection objectives. The values of physico-chemical and microbiological parameters of Tiaoxi River water were compared to the class III water quality category standards (applicable to the second class of protected areas for centralized sources of drinking water, protected areas for common fishes and swimming areas) as cited in "Environmental Quality Standards for 
Surface Water (GB3838-2002, GHZB1-1999)", MEP, PRC guidelines for surface water. The following physico-chemical parameters were analyzed in this study: air and water temperature, $\mathrm{pH}$, conductivity $(\mathrm{EC})$, total nitrogen $(\mathrm{TN})$, total phosphorous $(\mathrm{TP})$, nitrate $\left(\mathrm{NO}_{3}-\mathrm{N}\right)$, nitrite $\left(\mathrm{NO}_{2}-\mathrm{N}\right)$, phosphate $\left(\mathrm{PO}_{4}-\mathrm{P}\right)$, ammonia nitrogen $\left(\mathrm{NH}_{4}-\mathrm{N}\right)$, total organic carbon (TOC), and chlorophyll $a(\mathrm{Chl} a)$.

Temperature and conductivity were measured on-site with COM-100 handheld meter instruments (HM Digital Inc., Culver City, CA, USA) and pH was measured using a Eutech pH 700 instrument (Thermo Fisher Scientific Inc., Waltham, MA, USA). TN and TP were determined by peroxodisulphate oxidation and the spectrophotometric method. $\mathrm{NO}_{3}-\mathrm{N}, \mathrm{NO}_{2}-\mathrm{N}, \mathrm{NH}_{4}-\mathrm{N}$, and $\mathrm{PO}_{4}-\mathrm{P}$ were measured using a continuous flow analyzer (Skalar SA 1000, Breda, The Netherlands) as described in Wang et al. [33]. The TOC was measured by high-temperature oxidation with a Shimadzu analyzer (model 5000; Tokyo, Japan). Chl $a$ was measured by following the procedures recommended by American Public Health Association [34].

\subsection{Microbiological Parameters}

Total viable count (TVC) was determined by using plate count agar (LabM, Heywood, UK). Briefly, $100 \mu \mathrm{L}$ of each serially diluted water sample was aseptically plated onto agar plates in duplicate and incubated at $37^{\circ} \mathrm{C}$ for a maximum duration of $48 \mathrm{~h}$. The mean colony counts were expressed as $\mathrm{CFU} / \mathrm{mL}$ [35].

Total coliform (TC) bacteria were determined using Harlequin ${ }^{\mathrm{TM}}$ E. coli/Coliform medium (LabM, Heywood, UK). Briefly, $500 \mu \mathrm{L}$ of a 1:10 diluted sample was spread over the entire surface of the plate and incubated at $37^{\circ} \mathrm{C}$ for $24 \mathrm{~h}$. The average colony counts were expressed as CFU/1 mL [36].

Fecal coliform (FC) counts were carried out according to the membrane filtration method suggested by APHA [34]. Water samples were filtered through $0.45 \mu \mathrm{m}$ nitrocellulose filters (Millipore, Watford, UK) and the filters were placed on mFC agar (Difco, Sparks, MD, USA), and incubated at $44.5^{\circ} \mathrm{C}$ for $24 \mathrm{~h}$. Colonies that exhibited any shades of blue were counted and expressed as CFU $/ 100 \mathrm{~mL}$ surface water [34].

\subsection{Statistical Analyses}

The variations in physico-chemical and microbiological parameters (excluding fecal coliforms) across the sampling locations (spatial) and seasons were analyzed by one-way analysis of variance (ANOVA). Only the data which was available for all three seasons were used for statistical analysis. In total, physico-chemical and microbiological data (excluding fecal coliforms) collected from 19 locations in three seasons were used for further statistical analyses. The correlations between the bacterial counts (TVC, TC) and physicochemical parameters of water samples were determined by Spearman's nonparametric rank correlation test. The data transformation and the statistical analyses were performed using SPSS 22 version software (SPSS Inc., Chicago, IL, USA).

\subsubsection{Cluster Analysis}

Cluster analysis (CA) is a common technique for statistical data analysis and exploratory datamining applied in many fields of research as well as for water quality assessment [12,37]. With the aim of studying the spatial variability of water quality in Tiaoxi River basin and grouping similar sampling locations, hierarchical agglomerative clustering was performed using the normalized dataset. Ward's method of linkage with squared Euclidean distances was used as a measure of similarity [12]. Previous studies indicated that CA reliably classifies surface water quality and the results can be used as a guide for developing sampling strategies for the future [38,39].

\subsubsection{Principal Component Analysis/Factor Analysis}

Principal component analysis (PCA)/Factor analysis (FA) provides information on the most meaningful parameters which describe the whole data set, rendering data reduction with minimum loss of original information [40]. It is a powerful technique for pattern recognition that attempts to 
explain the variance of a large set of intercorrelated variables and transform them into a smaller set of independent (uncorrelated) variables called principal components [3]. In order to classify the variations of water quality, indicators (thirteen in total: water temperature, $\mathrm{pH}, \mathrm{EC}, \mathrm{TN}, \mathrm{TP}, \mathrm{NO}_{3}-\mathrm{N}, \mathrm{NO}_{2}-\mathrm{N}$, $\mathrm{PO}_{4}-\mathrm{P}, \mathrm{NH}_{4}-\mathrm{N}, \mathrm{TOC}, \mathrm{Chl} a, \mathrm{TVC}$, and TC) were used. PCA was executed using normalized variables to extract significant principal components (PCs) and these PCs were subjected to varimax rotation (raw) generating factors to further reduce the contribution of variables with minor significance [12,41].

\section{Results and Discussion}

\subsection{Physico-Chemical and Microbiological Parameters}

The results (range values) of physico-chemical and microbiological analyses from 25 sampling locations within Tiaoxi River across three seasons are summarized in Table 2. The surface water temperature (WT) was in the range of $22.3-26.6{ }^{\circ} \mathrm{C}$ in autumn, $6-8.8^{\circ} \mathrm{C}$ in winter, and $29-31.2{ }^{\circ} \mathrm{C}$ in summer. Water samples in all locations were within the $\mathrm{pH}$ range set by Ministry of Environmental Protection (MEP), People's Republic of China (PRC) for surface water and also natural water's $\mathrm{pH}$ limits (6.5-8.5) set for aquatic life and irrigation purposes [42]. Most natural water systems require a $\mathrm{pH}$ range of 6.5-8 to support a diverse aquatic population [43]. Significant statistical differences in $\mathrm{pH}$ were observed seasonally $(p<0.05)$; however, no spatial variation was observed. EC values were within the range of $124-400 \mu \mathrm{S} / \mathrm{cm}$ in all the locations and the values varied significantly with seasons $(p<0.05)$ (Table 2). For most freshwaters, the EC ranges from 10 to $1000 \mu \mathrm{S} / \mathrm{cm}$ and elevated levels of above $1000 \mu \mathrm{S} / \mathrm{cm}$ can be seen in polluted water or water bodies that receive large quantities of land runoff [42]. In streams and rivers, the conductivity is affected by various factors such as type of soils, bedrocks, and presence of inorganic dissolved solids. Sewage or wastewater could raise the conductivity due to the presence of chloride, phosphate, and nitrate [44].

Table 2. Summary of the results of physico-chemical and microbiological characteristics of Tiaoxi River water with statistical analyses.

\begin{tabular}{|c|c|c|c|c|c|c|}
\hline \multirow{2}{*}{ Parameters } & \multirow{2}{*}{ Acceptable Range (by MEP) } & \multicolumn{3}{|c|}{ Range (Minimum-Maximum) } & \multicolumn{2}{|c|}{$p$ value } \\
\hline & & Autumn 2014 & Winter 2015 & Summer 2015 & Season & Spatial \\
\hline WT $\left({ }^{\circ} \mathrm{C}\right)$ & - & $22.8-26.6$ & $6-8.8$ & $27.2-30.8$ & $0.0001 *$ & 0.712 \\
\hline $\mathrm{pH}$ & $6.5-8.5$ & $7.2-8$ & $7.4-7.9$ & $7.3-7.9$ & $0.112 *$ & 0.4546 \\
\hline $\mathrm{EC}(\mu \mathrm{S} / \mathrm{cm})$ & - & $153-400$ & $164-356$ & $124-234$ & $0.0102 *$ & 0.6564 \\
\hline $\mathrm{TN}(\mathrm{mg} / \mathrm{L})$ & $\leq 1 \mathrm{mg} / \mathrm{L}$ & $1.78-4.13$ & $1.3-4.03$ & $1.88-3.11$ & 0.5209 & $0.0001^{* * *}$ \\
\hline $\mathrm{TP}(\mathrm{mg} / \mathrm{L})$ & $\leq 1 \mathrm{mg} / \mathrm{L}\left(\leq 0.05^{\mathrm{a}}\right)$ & $0.07-0.18$ & $0.07-0.19$ & $0.08-0.14$ & $0.0001^{* * *}$ & $0.0001^{* * *}$ \\
\hline $\mathrm{NO}_{3}-\mathrm{N}(\mathrm{mg} / \mathrm{L})$ & $\leq 10 \mathrm{mg} / \mathrm{L}$ & $0.84-3.43$ & $0.376-3.39$ & $1.07-2.02$ & 0.2464 & $0.0220 *$ \\
\hline $\mathrm{NO}_{2}-\mathrm{N}(\mathrm{mg} / \mathrm{L})$ & $\leq 0.15 \mathrm{mg} / \mathrm{L}$ & $0.02-0.16$ & $0.002-0.05$ & $0.04-0.18$ & 0.9987 & $0.0011^{* *}$ \\
\hline $\mathrm{PO}_{4}-\mathrm{P}(\mu \mathrm{g} / \mathrm{L})$ & -0 & $2.4-38.2$ & $3.2-35.24$ & $6.8-51.9$ & 0.1324 & $0.0001 * * *$ \\
\hline $\mathrm{NH}_{4}-\mathrm{N}(\mathrm{mg} / \mathrm{L})$ & $\leq 1 \mathrm{mg} / \mathrm{L}$ & $0.013-1$ & $0.05-1.025$ & $0.02-0.81$ & $0.0001^{* * *}$ & $0.0001^{* * *}$ \\
\hline TOC (mg/L) & - & $2.38-8.46$ & $14.9-268.9$ & $1.9-13.7$ & 0.2929 & $0.0083 * *$ \\
\hline $\mathrm{Chl} a(\mu \mathrm{g} / \mathrm{L})$ & - & $36.3-103.4$ & $29.8-89.3$ & $49.1-132.6$ & $0.0001^{* * *}$ & $0.0001^{* * *}$ \\
\hline TVC (Log10 CFU/mL) & - & $3.57-4.28$ & $3.06-4.34$ & $3.60-4.19$ & 0.3078 & 0.2454 \\
\hline TC (Log10 CFU/mL) & 1 & $1.60-3.30$ & $2.0-3.31$ & $2.22-3.61$ & 0.328 & $0.0025 * *$ \\
\hline FC ( $\log 10 \mathrm{CFU} / 100 \mathrm{~mL})$ & & - & $2.0-3.45$ & $1.69-3.62$ & - & $0.0055^{* *}$ \\
\hline
\end{tabular}

The seasonal and spatial variations in $\mathrm{TN}, \mathrm{TP}, \mathrm{NO}_{3}-\mathrm{N}, \mathrm{NO}_{2}-\mathrm{N}, \mathrm{PO}_{4}-\mathrm{P}, \mathrm{NH}_{4}-\mathrm{N}$, TOC, and Chl $a$ are shown in Figure 2A-D and Figure 3A-D. Among all these parameters tested, only $\mathrm{TP}, \mathrm{NH}_{4}-\mathrm{N}$, and $\mathrm{Chl} a$ showed significant $(p<0.001)$ seasonal and spatial variations (Table 2$)$. The parameters TN, $\mathrm{NO}_{3}-\mathrm{N}, \mathrm{NO}_{2}-\mathrm{N}$, and TOC showed significant $(p<0.05)$ spatial variations. Based on MEP guidelines, $\mathrm{TN}$ values were outside the acceptable limits $(\geq 1 \mathrm{mg} / \mathrm{L})$ in all locations for all seasons. The highest TN values $(4.13 \mathrm{mg} / \mathrm{L})$ were reported in samples collected from Location 18 in Autumn 2014 (Figure 2A), and this location is near to a suburban/industrial area (junction of Changxing and Tiaoxi River) with ferry docking facilities. The sources for elevated levels of TN in water bodies include runoff from agricultural croplands and animal manure, discharge from wastewater treatment plants (WWTPs), 
and leakage from septic tanks [45]. The presence of elevated levels of TN and ammonia in water is considered indicative of freshly polluted water by environmental management engineers [46]. As per MEP guidelines, the acceptable TP levels for class III water bodies is $<0.2 \mathrm{mg} / \mathrm{L}$, but for lakes and reservoirs, the TP levels should be $<0.05 \mathrm{mg} / \mathrm{L}$. Here, TP levels were outside the acceptable range in Location 1 (Taihu Lake, $1 \mathrm{~km}$ inside from Taihu Lake/Tiaoxi River junction) and the levels were closer to acceptable limits in Location 16 for the autumn $(175.58 \mu \mathrm{g} / \mathrm{L})$ and winter $(187.42 \mu \mathrm{g} / \mathrm{L})$ seasons (Figure 2B). Location 16 is a suburban mixed residential and business area and the samples were collected at a junction between the main river and a canal that connects to Taihu Lake (Table 2). Zheng et al. [31] reported higher levels of TP and TN in Catchment 8 (urban land) of East Tiaoxi River; this area has two WWTPs, one of which is located near sampling locations 15 and 16 of the current study. The higher levels of TP observed at Location 16 could be due to effluents from the WWTP. As stated above, the concentrations of TP showed significant seasonal and spatial variation $(p<0.001)$ and TP levels were comparatively high for most of the locations in winter 2015. Wang et al. [27] reported similar TP levels for rivers surrounding Taihu Lake. Possible runoff from fertilized lawns and cropland, animal manure, and also domestic sewage entry into the water are likely causes [47]. $\mathrm{NO}_{3}-\mathrm{N}$ levels were within acceptable limits $(<10 \mathrm{mg} / \mathrm{L})$ as suggested by MEP but elevated levels of $\mathrm{NO}_{2}-\mathrm{N}(>0.15$ $\mathrm{mg} / \mathrm{L}$ ) were observed in Location 3 in autumn and in Locations 15 and 16 during the summer season (Figure 2C,D). Sources of $\mathrm{NO}_{2}-\mathrm{N}$ include human sewage, livestock manure, fertilizers, and erosion of natural deposits [48]. Location 3 is a fishing village where people live on boats stationed at this location. Locations 15 and 16 are in a suburban area and the sampling was conducted in a junction between Tiaoxi River and a canal that connects to Taihu Lake where boats/ferries were docked. The higher levels of $\mathrm{NO}_{2}-\mathrm{N}$ observed in these three locations may be due to the entry of human sewage into the water. A previous study showed that presence of higher concentrations of $\mathrm{NO}_{2}-\mathrm{N}$ in water is a potential problem due to its toxicity to humans (more potential health effects are seen in infants) and livestock when consumed [49].

$\mathrm{NH}_{4}-\mathrm{N}$ levels were outside standard limits $(>1 \mathrm{mg} / \mathrm{L})$ in Location 16 in autumn and at Location 24 in winter (Figure 3B). $\mathrm{NH}_{4}-\mathrm{N}$ enters into water mostly from anthropogenic sources such as human sewage, municipal effluent discharges, livestock manure, and agricultural runoff. Elevated levels of NH4-N in surface water primarily exert toxic effects on the higher aquatic organisms such as fish and shrimps [50]. Xu et al. [51] reported similar results for surface water quality in the Taihu watershed. There are no specific standards for $\mathrm{PO}_{4}-\mathrm{P}$ as per MEP, PR China, but a concentration of $<20 \mu \mathrm{g} / \mathrm{L}$ is commonly present in streams and rivers. Elevated levels of $>20 \mu \mathrm{g} / \mathrm{L}$ indicate pollution and can lead to excessive algal growth [52]. In the present study, $\mathrm{PO}_{4}-\mathrm{P}$ levels were high in all locations (Figure 3A) on one or more occasions; however, no significant correlation between $\mathrm{PO}_{4}-\mathrm{P}$ and $\mathrm{Chl} a$ was observed (Table 3). Similarly, for TOC there are no specific standards set by MEP, PRC. Both $\mathrm{PO}_{4}-\mathrm{P}$ and TOC levels showed statistically significant $(p<0.05)$ spatial variation (Table 2, Figure 3C,D). Most of the surface waters with low nutrient levels have $\mathrm{Chl} a$ levels of $<2.5 \mu \mathrm{g} / \mathrm{L}$, but higher levels can be seen if there is high nutrient availability [42]. In the current study, all locations showed higher Chl $a$ levels in all seasons, indicating high algal growth in Tiaoxi River water (Figure 3D). Chlorophyll $a$ levels were high in the summer season followed by in autumn and winter, which can be correlated with warm temperatures in the summer and autumn seasons and the availability of nutrients. In general, the concentration of Chl $a$ was high if the location had a high TP concentration. Xu et al. (2010) [53] reported similar results for $\mathrm{Chl} a$ levels in Taihu Lake water. The prevalence of cyanobacteria and higher concentrations of Chl $a$ during the summer season in Taihu Lake has been reported previously [23,52]. The highest Chl $a$ levels were observed at Locations 1, 12, and 23 during the summer season, and Chl $a$ concentrations were statistically significant both spatially and seasonally $(p<0.05)$ (Table 2). 


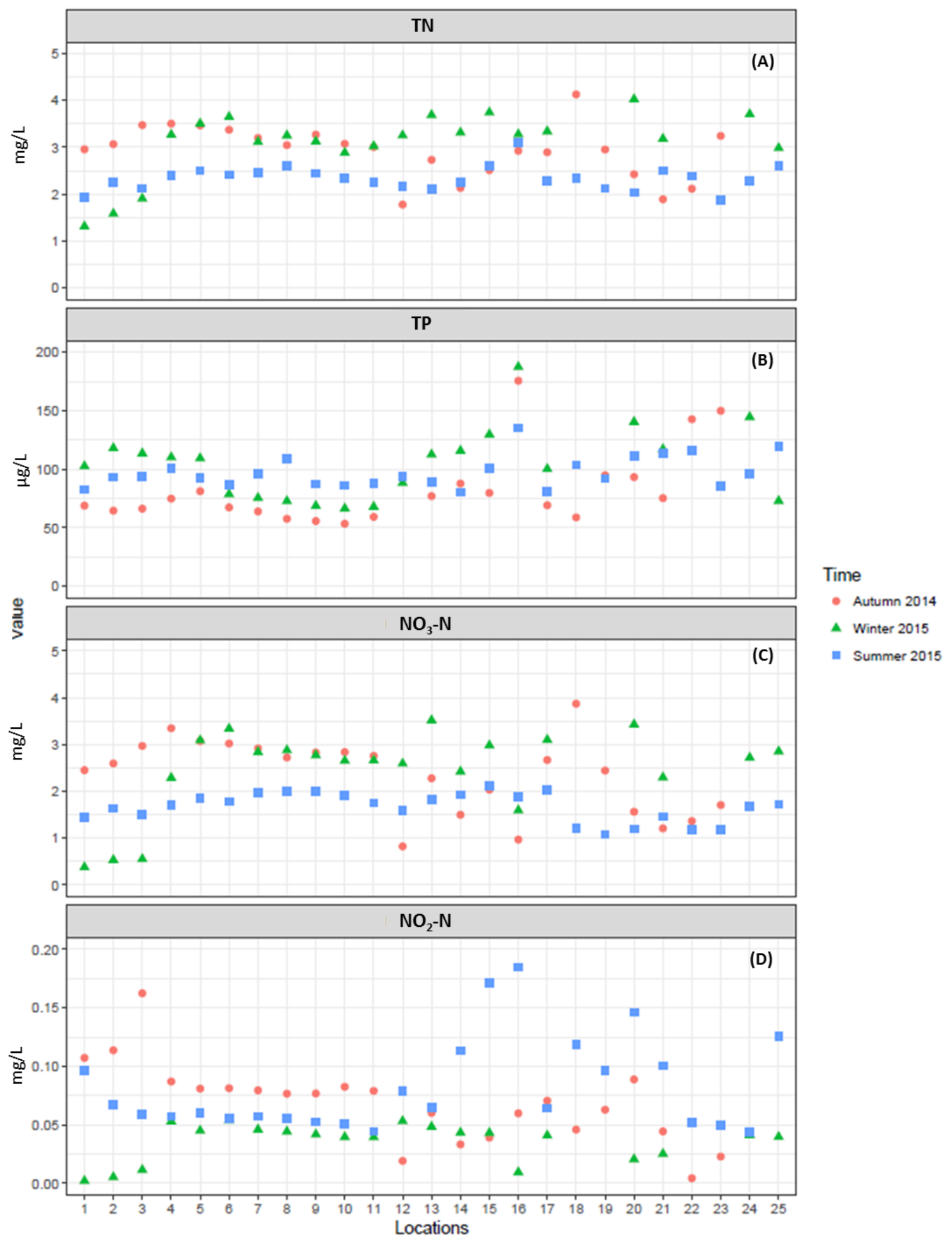

Figure 2. Spatial and temporal variations in physico-chemical parameters: Total Nitrogen (A), Total Phosphorus (B), Nitrate-N (C), Nitrite-N (D). 

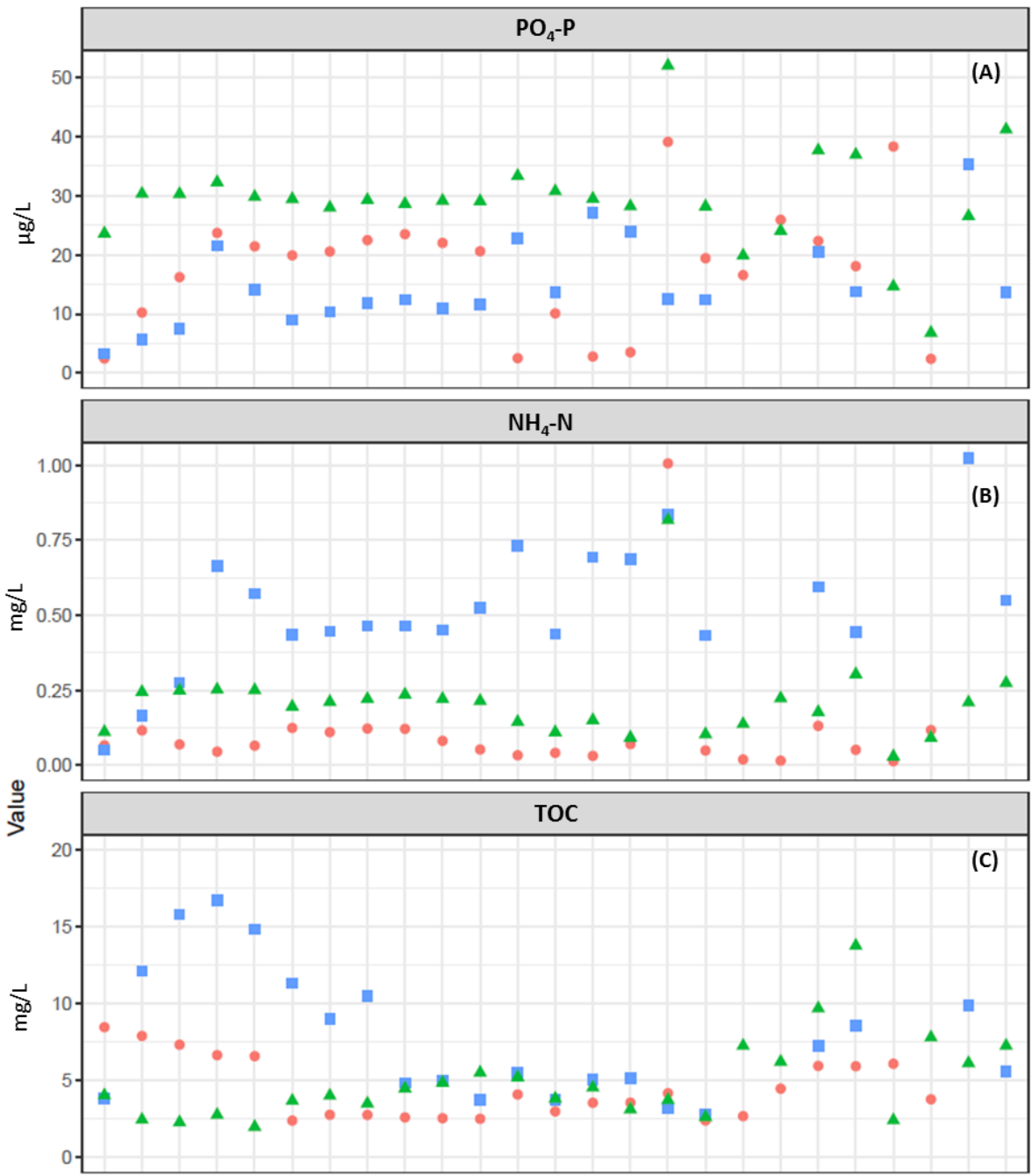

- Autumn 2014

- Summer 2015

ㅁ Winter 2015

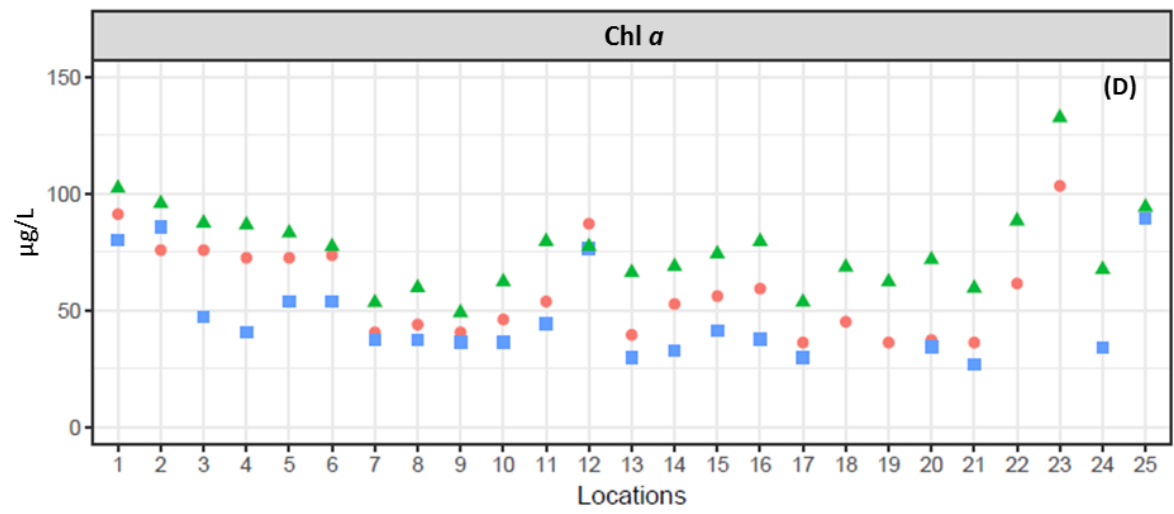

Figure 3. Spatial and temporal variations in physico-chemical parameters: Phosphate-P (A), Ammonium-N (B), Total Organic Carbon (C), Chlorophyll $a$ (D). 
Table 3. Spearman's correlation coefficient $(r)$ values observed between different water quality parameters.

\begin{tabular}{|c|c|c|c|c|c|c|c|c|c|c|c|c|c|}
\hline Parameters & WT & $\mathrm{pH}$ & EC & TN & TP & $\mathrm{NO}_{3}-\mathrm{N}$ & $\mathrm{NO}_{2}-\mathrm{N}$ & $\mathrm{PO}_{4}-\mathrm{P}$ & $\mathrm{NH}_{4}-\mathbf{N}$ & TOC & Chl $a$ & TVC & TC \\
\hline WT & 1 & & & & & & & & & & & & \\
\hline $\mathrm{pH}$ & 0.03 & 1 & & & & & & & & & & & \\
\hline EC & 0.22 & $0.80 * *$ & 1 & & & & & & & & & & \\
\hline $\mathrm{TN}$ & -0.15 & -0.35 & -0.35 & 1 & & & & & & & & & \\
\hline $\mathrm{TP}$ & 0.17 & $0.74^{* *}$ & $0.78^{* *}$ & 0.08 & 1 & & & & & & & & \\
\hline $\mathrm{NO}_{3}-\mathrm{N}$ & -0.16 & $-0.61^{* *}$ & $-0.73^{* *}$ & $0.65 * *$ & 0.45 * & 1 & & & & & & & \\
\hline $\mathrm{NO}_{2}-\mathrm{N}$ & 0.34 & 0.16 & $0.46^{*}$ & 0.23 & $0.54 *$ & -0.24 & 1 & & & & & & \\
\hline $\mathrm{PO}_{4}-\mathrm{P}$ & 0.27 & 0.06 & -0.02 & $0.49 *$ & 0.28 & 0.10 & -0.01 & 1 & & & & & \\
\hline $\mathrm{NH}_{4}-\mathrm{N}$ & -0.17 & 0.25 & 0.23 & $0.45^{*}$ & 0.53 * & -0.08 & 0.16 & $0.73^{* *}$ & 1 & & & & \\
\hline TOC & 0.57 * & -0.15 & 0.24 & -0.08 & 0.21 & -0.16 & 0.23 & 0.15 & 0.12 & 1 & & & \\
\hline Chl $a$ & -0.02 & 0.06 & 0.33 & -0.23 & 0.12 & -0.41 & 0.34 & -0.37 & 0.01 & 0.33 & 1 & & \\
\hline TVC & 0.09 & 0.29 & 0.30 & 0.27 & $0.50 *$ & -0.13 & $0.59^{* *}$ & 0.01 & 0.32 & 0.125 & 0.37 & 1 & \\
\hline $\mathrm{TC}$ & -0.03 & 0.18 & 0.19 & 0.24 & 0.36 & -0.12 & 0.50 * & -0.11 & 0.25 & 0.037 & $0.47^{*}$ & $0.80 * *$ & 1 \\
\hline
\end{tabular}

* The correlation was significant at $p<0.05$; ${ }^{* *}$ The correlation was significant at $p<0.01$.

\section{Microbiological Parameters}

TVC was carried out to enumerate aerobic/facultative anaerobic mesophiles in the surface water, primarily to determine whether these counts showed any relationship with physico-chemical parameters and coliform counts. TVC values neither showed any seasonal or spatial significance statistically nor followed a similar trend to total coliform and fecal coliform numbers (Table 2, Figure 4A). As per MEP standards, the suggested standard limit for total/fecal coliforms for level III water bodies is $<10,000 / \mathrm{L}$ ( or $<10 / \mathrm{mL}$ ) but elevated levels of total coliforms were observed in all locations for all seasons, and much higher levels were observed in seven locations (Locations 2, 3, 5, 12, $15,16$, and 17) on one or more occasions with the highest at Location 16 ( $3.61 \log 10 \mathrm{CFU} / \mathrm{mL})$ during the summer season (Figure 4B). The results correlate well with the land use pattern or possible mixing of waste in the above locations where either boats/ferries were docked or leakage of waste into the river through human activities was observed. Hagedorn and Liang [28] also indicated a serious fecal contamination of Tiaoxi River and reported higher levels $(2.54 \log 10 \mathrm{CFU} / \mathrm{mL})$ of E. coli for the water samples collected near Fengkou drinking water station. TC showed statistically significant $(p<0.005)$ differences between locations (Table 2, Figure 4C). Previously, total coliforms were considered as bacterial water quality indicators to assess fecal contamination in recreational waters in the USA, as required by the Beaches Environmental Assessment and Coastal Health Act [54] to reduce health risks. However, it was reported that some members of the coliform group live in the environment (i.e., outside of the gastrointestinal tract), which may show a false indication for fecal contamination in water [55]. Therefore, TC counts are no longer used as an indicator for recreational waters as they are widespread in nature, but are still used to assess drinking water quality [44] . Fecal coliform (FC) counts are used as guidelines for microbial water quality to assess fecal contamination. In the present study, most of the locations showed higher levels of FC (>250 CFU/100ml) in the winter and summer seasons (Figure 4C) as compared to USEPA standards; however, no guidelines were suggested by MEP for FC in surface water in China. A high FC count was observed in five locations (Locations 2, 3, 5, $12,16)$ on one or more occasions with the highest at Location $16(3.62 \log 10 \mathrm{CFU} / 100 \mathrm{~mL})$ during the summer season. As indicated previously, these are the locations near residential areas where people either live on boats without adequate sanitation facilities, or urban residential areas with multiple waste inputs into the rivers such as leakage of waste from unknown sources. The higher levels of FC observed in these locations could be correlated with the discharge of effluent from a WWTP located near Locations 15 and 16. Only some fecal coliforms are pathogenic and a previous study showed that FC presence does not always correlate with pathogen presence [56]. However, a high FC count implies impaired water quality and increased risk associated with the presence of pathogens [57]. FC levels were comparatively higher in summer than in winter; this may be due to the runoff and heavy rainfall that occurred before summer sampling in 2015. The increased concentrations of fecal coliforms after 
rainfall events have been widely acknowledged in scientific literature $[4,21,58]$. The higher levels of FC observed could also be due to warm temperatures, which can facilitate FC bacteria accustomed to such conditions [59]. FC numbers showed significant spatial $(p<0.05)$ variation.

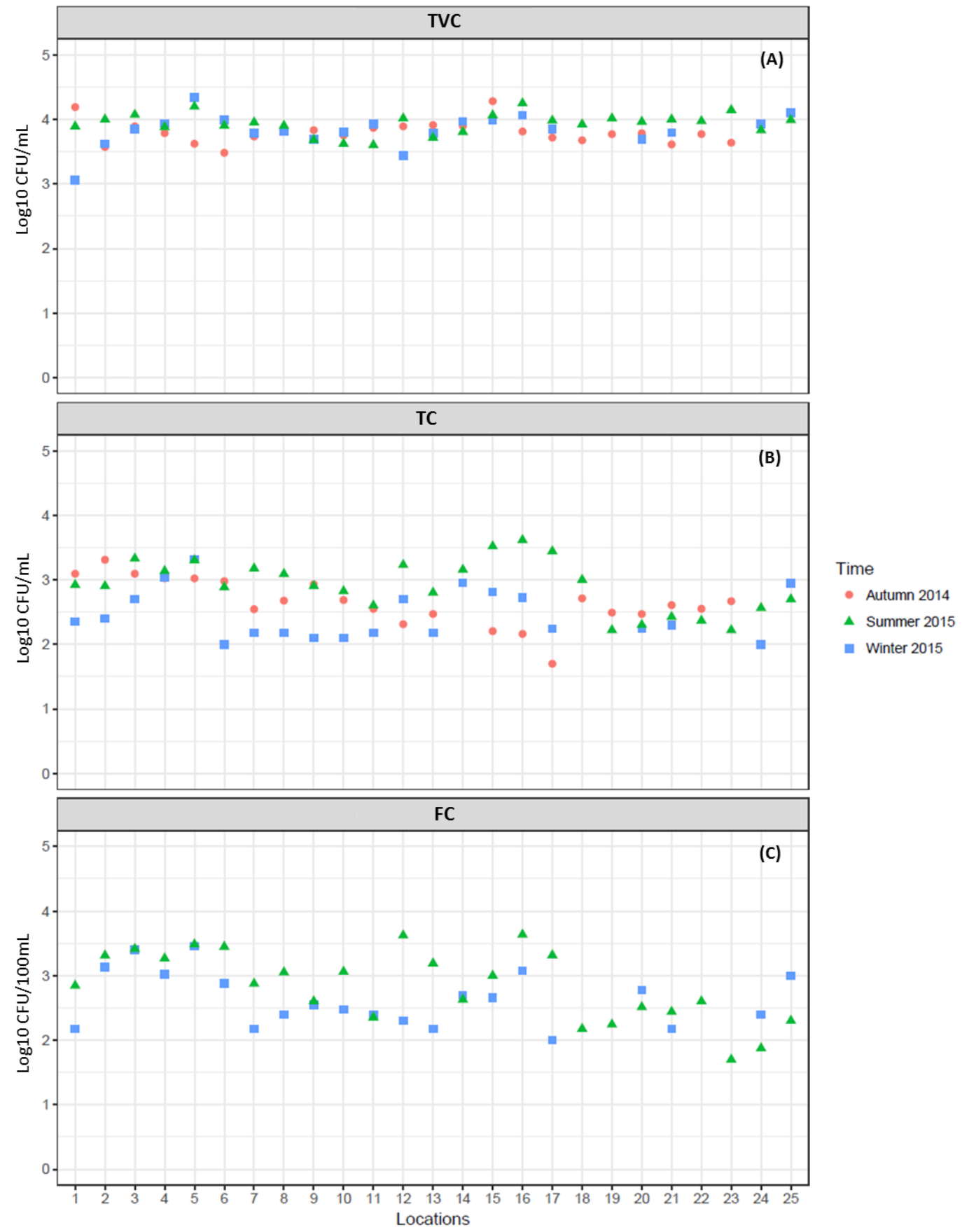

Figure 4. Spatial and temporal variations in microbiological parameters: Total viable count (A), Total coliforms (B), Fecal coliforms (C).

\subsection{Correlation Between Variables}

Results of correlation analysis (Table 3 ) showed that TN has a moderate positive correlation with $\mathrm{NO}_{3}-\mathrm{N}(r=0.651)$ and a weak correlation with $\mathrm{PO}_{4}-\mathrm{P}(r=0.486)$ and $\mathrm{NH}_{4}-\mathrm{N}(r=0.448)$, which suggests that $\mathrm{NO}_{3}-\mathrm{N}$ could be the major contributor of TN [10]. TP has moderate positive correlation with $\mathrm{NO}_{2}-\mathrm{N}$ and $\mathrm{NH}_{4}-\mathrm{N}$, indicating probably a common source of organic contamination such as untreated 
sewage [60]. TP also has a strong positive correlation with EC, and a moderate positive correlation with the microbiological parameters (TVC). Microbiological parameters (TVC and TC) showed a positive correlation with each other $(r=0.796)$ and also with some of the nutrients ( $\mathrm{TP}$ and $\left.\mathrm{NO}_{2}-\mathrm{N}\right)$, indicating possible microbial contaminations from sewage [5]. $\mathrm{pH}$ had a strong positive correlation with EC, and $\mathrm{NO}_{3}-\mathrm{N}$ had a strong negative correlation with EC. No obvious correlation $(r<0.4)$ was observed among the other parameters.

\subsection{Cluster Analysis for Spatial Grouping}

Cluster analysis (CA) was applied to group sampling locations with similar water quality characteristics. A dendrogram generated by CA grouped the 19 locations into three clusters at (Dlink/Dmax) $<60$ (Figure 5). The CA results are convincing, as the generated clusters share similar characteristic features and land use patterns. Based on the physico-chemical and microbiological results, each cluster was classified into respective pollution categories (Supplementary Table S1). Cluster 1 includes eight locations (Locations 6-11,13, and 17) and consists of mixed land use, either rural or urban/suburban residential areas with little industrial activity, corresponding to a relatively low level of pollution. Cluster 2 comprises four locations $(4,5,15$, and 16) which are mostly the junctions of East and West Tiaoxi River or other streams. These locations are predominantly close to urban and semi-urban residential areas with large-scale business, ferry transportation, and ferry docking activities, and in some of these locations, entry of wastewater to the river was noticed during sampling (Figure 6). This cluster was classified as highly polluted based on the physico-chemical and microbiological results. Cluster 3 comprises seven locations (1, 2, 3, 12, 14, 20, and 21), and includes mixed land use and can be categorized as moderately polluted locations based on physico-chemical and microbiological analysis. Sampling locations 20 and 21 were close to sparse residential/industrial areas and Locations 2 and 3 are residential areas where a few people are living on boats (Figure 6). The CA enabled us to categorize sampling locations based on water quality, so that in future studies, the number of sampling locations can be minimized for cost-effective monitoring of water quality in Tiaoxi River by choosing a few locations from each cluster based on the distance distribution and pollution levels in those locations. Previous studies have reported that a similar strategy has been successfully applied in water quality monitoring programs elsewhere $[12,13,61,62]$, and the Tiaoxi River Taihu catchment is therefore similarly amenable to this rational approach.

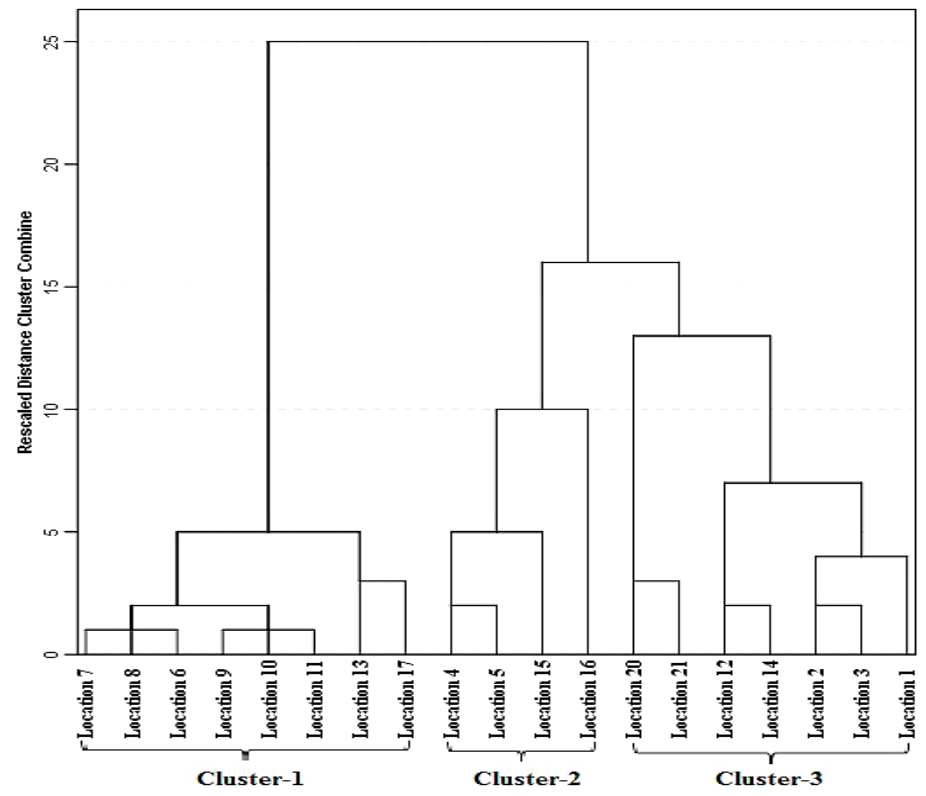

Figure 5. Dendogram showing clustering of sampling locations based on surface water quality characteristics of the Tiaoxi River. 

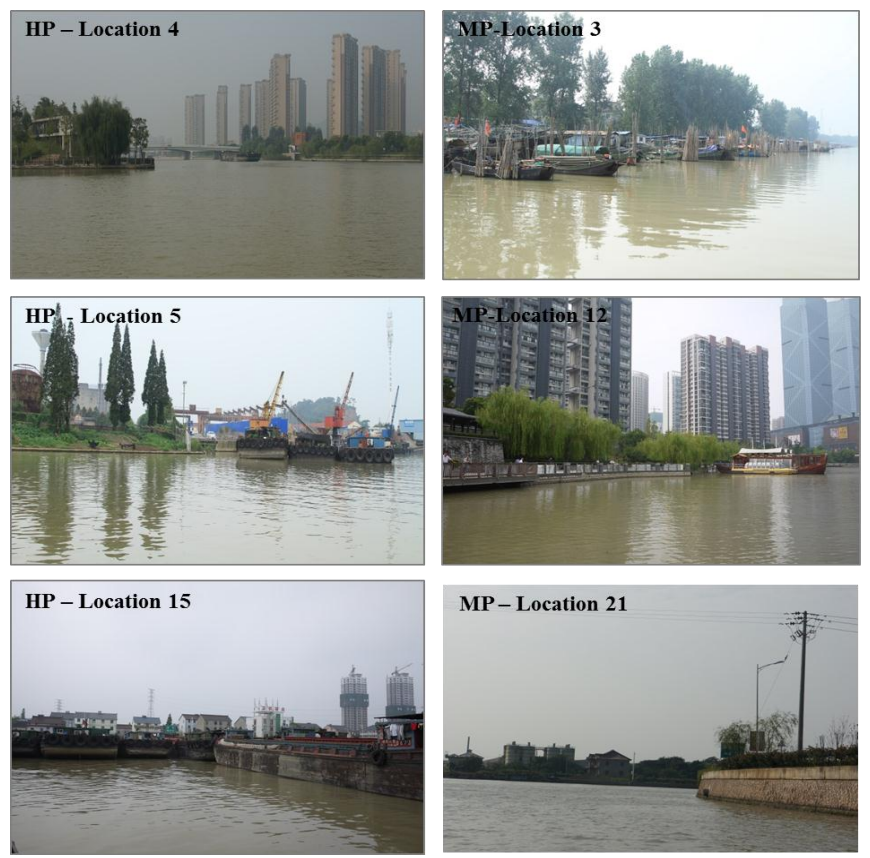
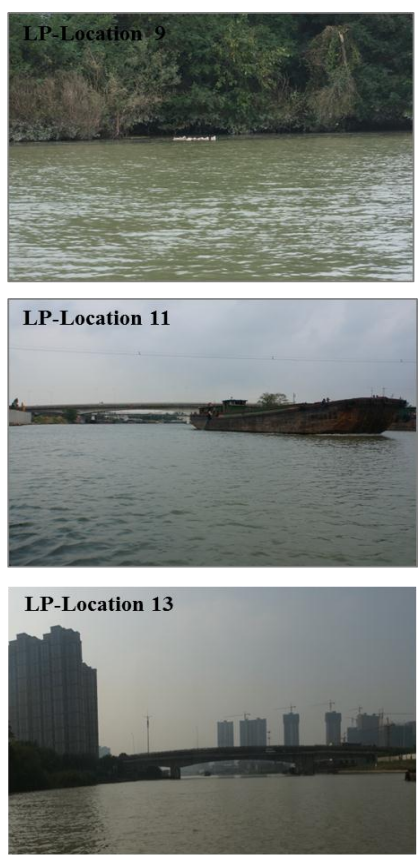

Figure 6. Sampling locations representing high (HP), medium (MP), and low (LP) pollution risk locations.

\subsection{Principal Component Analysis/Factor Analysis for Source Identification}

Principal component analysis (PCA)/Factor analysis (FA) was performed using log transformed data to identify the factor(s) that influence the water quality during the entire sampling period and within the seasons (autumn, winter, and summer). Kaiser-Meyer-Olkin (KMO) and Bartlett's tests were carried out to verify the suitability of data for PCA/FA. A KMO value of 0.5 or more is required to perform PCA and a lower KMO value indicates that the dataset is not suitable for PCA [14].

In this study, the KMO value for the entire dataset was 0.53; however, the Bartlett's test gave a $p$ value of $<0.001$, indicating the suitability of the data for PCA. The significance of the factor is evaluated by eigenvalue in PCA; the higher the eigenvalues, the higher the significance of factors, with 1.0 or greater eigenvalues considered significant [12]. The PCA for the entire dataset yielded four PCs (with eigenvalues $\geq 1$ ), which explained over $83 \%$ of the total variance in the dataset. The variable loadings on varimax-rotated PCs for the entire data set are provided in Table 4. Variable loading is classified as "strong", "moderate", or "weak", corresponding to their absolute loading values of $>0.75$, $0.75-0.50$, and $0.50-0.30$, respectively [63].

The first component (VF1) accounted for $32.2 \%$ of the total variance and has strong positive loading for $\mathrm{pH}, \mathrm{EC}$, and $\mathrm{TP}$, and strong negative loading for $\mathrm{NO}_{3}-\mathrm{N}$, indicating variability in physico-chemical sources (Table 4). Normally, EC is used to indicate natural pollution and can be due to soil erosion or weathering effects on water quality during seasonal changes [14]. This component also suggests that most of the variation is due to $\mathrm{pH}$ and EC changes. The second component (VF2) is responsible for $25.4 \%$ of the total variance and showed strong positive loading for $\mathrm{TN}, \mathrm{PO}_{4}-\mathrm{P}$, and $\mathrm{NH}_{4}-\mathrm{N}$. This component also gave moderate negative loading to $\mathrm{Chl} a$, indicating nutrient pollution; this could be interpreted as influences from agricultural and domestic waste [64]. The third component (VF3) explained $14.2 \%$ of the total variance and has strong positive loading for TVC and TC. This component also has moderate positive loading for $\mathrm{Chl} a$ and represents influences of mainly microbial origin. The microbial factor TC can be associated with sewage pollution in the river. The fourth component (VF4), accounting for $12 \%$ of the total variance, has strong positive loading for WT and TOC. This component represents physico-chemical sources and could be interpreted as influences from organic pollution 
caused by domestic and industrial discharges. Similar results have been reported by other authors for water quality assessment by PCA/FA $[10,64]$.

Table 4. Loadings of thirteen variables on Varimax-rotated principal components.

\begin{tabular}{ccccc}
\hline \multirow{2}{*}{ Parameters } & \multicolumn{4}{c}{ Components } \\
\cline { 2 - 4 } & VF1 & VF2 & VF3 & VF4 \\
\hline WT & 0.134 & 0.121 & -0.173 & $\mathbf{0 . 8 5 7}$ \\
pH & $\mathbf{0 . 9 1 1}$ & 0.131 & -0.003 & -0.160 \\
$\mathrm{EC}$ & $\mathbf{0 . 9 2 6}$ & -0.086 & 0.182 & 0.207 \\
$\mathrm{TN}$ & -0.474 & $\mathbf{0 . 8 3 7}$ & 0.181 & -0.056 \\
$\mathrm{TP}$ & $\mathbf{0 . 7 5 5}$ & 0.443 & 0.393 & 0.172 \\
$\mathrm{NO}_{3}-\mathrm{N}$ & $\mathbf{0 . 8 0 8}$ & 0.388 & -0.123 & -0.195 \\
$\mathrm{NO}_{2}-\mathrm{N}$ & 0.385 & 0.279 & 0.495 & 0.392 \\
$\mathrm{PO}_{4}-\mathrm{P}$ & 0.088 & $\mathbf{0 . 9 3 8}$ & -0.024 & 0.127 \\
$\mathrm{NH}_{4}-\mathrm{N}$ & 0.175 & $\mathbf{0 . 8 6 6}$ & 0.195 & -0.076 \\
$\mathrm{TOC}$ & 0.013 & -0.170 & 0.114 & $\mathbf{0 . 8 6 1}$ \\
$\mathrm{Chl} a$ & 0.145 & $-\mathbf{0 . 6 0 2}$ & $\mathbf{0 . 5 8 9}$ & 0.168 \\
$\mathrm{TVC}$ & 0.183 & 0.183 & $\mathbf{0 . 8 4 8}$ & 0.010 \\
$\mathrm{TC}$ & 0.030 & -0.030 & $\mathbf{0 . 8 8 5}$ & -0.140 \\
Eigenvalue & 4.186 & 3.297 & 1.843 & 1.567 \\
\%otal variance & 32.197 & 25.365 & 14.174 & 12.054 \\
Cumulative $\%$ variance & 32.197 & 57.562 & 71.735 & 83.786 \\
\hline
\end{tabular}

Values in bold indicate strong or moderate loadings.

\section{Conclusions}

In this study, a detailed physico-chemical and microbiological analysis was carried out to assess the quality of Tiaoxi River water. The results of the physico-chemical analysis indicated that TN, TP, $\mathrm{NO}_{2}-\mathrm{N}$, and $\mathrm{NH}_{4}-\mathrm{N}$ are the major nutrients that contribute to pollution in this river. The multiple nutrients and bacterial counts vary with the type of land-use and locations, where nonpoint sources possibly enter the Tiaoxi River. The entry of wastes into this river from nonpoint sources was observed in several locations during the sampling events and these wastes negatively affect the Tiaoxi River and Taihu water quality. The elevated levels of nutrients contribute to eutrophication that is evident from the presence of high concentrations of $\mathrm{Chl} a$, particularly in Location 1 (Taihu Lake), due to algal blooms in the lake. Chl $a$ levels were comparatively high in the samples collected during the summer season, which can be correlated with warm temperatures in summer and availability of nutrients. The bacterial counts were higher in urban/semi-urban locations where wastes from nonpoint sources entered into the river. The microbiological results also indicated that fecal pollution was high in 15 locations, suggesting the entry of human or animal fecal matter into the river. Cluster analysis showed that the sampling locations can be grouped into three clusters based on the land use patterns and physico-chemical and microbiological analysis data, and these three clusters can be classified as relatively low, moderate, and high pollution areas. The PCA of the entire dataset reduced the parameters to four principal components that explain $83 \%$ of the total variance. The four components that contribute significant variation in water can be classified as natural, nutrient, microbial, and organic types of pollutants.

The overall physico-chemical and microbiological results indicate the possibility of fecal source entry into the river through various sources. A microbial source tracking study is underway to determine the major fecal source contributing to this pollution in the Taihu watershed.

Supplementary Materials: The following are available online at http:/ /www.mdpi.com/2073-4441/10/2/183/s1, Table S1: Range of physico-chemical and microbiological characteristics for locations in which pollution is classified as relatively low, moderate, or high.

Acknowledgments: The authors would like to acknowledge the Natural Science Foundation of Jiangsu Province (Jiangsu Science and Technology Programme; Grant No. BK20141211), Jiangsu Provincial Department of Education (Jiangsu University Natural Science Programme, Grant No. 13KJB180022), Suzhou Industrial Park Supplement 
Fund and Xi'an Jiaotong-Liverpool University (XJTLU) for funding support. The authors would also like to thank Department of Biological Sciences, XJTLU for providing research facilities. Financial support to Kiran Kumar Vadde and Tianma Yuan was provided through Postgraduate Research Scholarship (PGRS-12-01-08 and PGRS-13-03-09, respectively) awarded by XJTLU.

Author Contributions: Raju Sekar, Jianjun Wang and Alan J. McCarthy conceived and designed the experiments; Raju Sekar, Kiran Kumar Vadde, Long Cao and Tianma Yuan carried out the field sampling; Jianjun Wang contributed to nutrient analyses; Kiran Kumar Vadde carried out the microbiological and statistical analyses and prepared the paper with the direction of his supervisors Raju Sekar and Alan J. McCarthy; Long Cao prepared the map of the sampling locations; Raju Sekar, Alan J. McCarthy and Jianjun Wang contributed to revision of the paper; and Tianma Yuan formatted the paper.

Conflicts of Interest: The authors declare no conflict of interest.

\section{References}

1. Noori, R.; Sabahi, M.S.; Karbassi, A.R.; Baghvand, A.; Taati Zadeh, H. Multivariate statistical analysis of surface water quality based on correlations and variations in the data set. Desalination 2010, 260, 129-136. [CrossRef]

2. Lodder, W.J.; van den Berg, H.H.; Rutjes, S.A.; de Roda Husman, A.M. Presence of enteric viruses in source waters for drinking water production in The Netherlands. Appl. Environ. Microbiol. 2010, 76, 5965-5971. [CrossRef] [PubMed]

3. Ouyang, Y. Evaluation of river water quality monitoring stations by principal component analysis. Water Res. 2005, 39, 2621-2635. [CrossRef] [PubMed]

4. Carroll, S.P.; Dawes, L.; Hargreaves, M.; Goonetilleke, A. Water Quality Profile of an Urbanising Catchment-Ningi Creek Catchment; Technical Report; School of Urban Development, Queensland University of Technology: Caboolture Shire Council, QLD, Australia, 2006; pp. 1-93.

5. Nnane, D.E.; Ebdon, J.E.; Taylor, H.D. Integrated analysis of water quality parameters for cost-effective faecal pollution management in river catchments. Water Res. 2011, 45, 2235-2246. [CrossRef] [PubMed]

6. Hill, M.K. Understanding Environmental Pollution, 3rd ed.; Cambridge University Press: Cambridge, UK, 2010.

7. Bu, H.; Meng, W.; Zhang, Y. Spatial and seasonal characteristics of river water chemistry in the Taizi River in northeast China. Environ. Monit. Assess. 2014, 186, 3619-3632. [CrossRef] [PubMed]

8. Razmkhah, H.; Abrishamchi, A.; Torkian, A. Evaluation of spatial and temporal variation in water quality by pattern recognition techniques: A case study on jajrood river (Tehran, Iran). J. Environ. Manag. 2010, 91, 852-860. [CrossRef] [PubMed]

9. Li, S.; Li, J.; Zhang, Q. Water quality assessment in the rivers along the water conveyance system of the middle route of the south to north water transfer project (China) using multivariate statistical techniques and receptor modeling. J. Hazard. Mater. 2011, 195, 306-317. [CrossRef] [PubMed]

10. Mei, K.; Liao, L.; Zhu, Y.; Lu, P.; Wang, Z.; Dahlgren, R.A.; Zhang, M. Evaluation of spatial-temporal variations and trends in surface water quality across a rural-suburban-urban interface. Environ. Sci. Pollut. Res. 2014, 21, 8036-8051. [CrossRef] [PubMed]

11. Wang, X.; Cai, Q.; Ye, L.; Qu, X. Evaluation of spatial and temporal variation in stream water quality by multivariate statistical techniques: A case study of the xiangxi river basin, China. Quat. Int. 2012, 282, 137-144. [CrossRef]

12. Shrestha, S.; Kazama, F. Assessment of surface water quality using multivariate statistical techniques: A case study of the fuji river basin, Japan. Environ. Model. Softw. 2007, 22, 464-475. [CrossRef]

13. Singh, K.P.; Malik, A.; Sinha, S. Water quality assessment and apportionment of pollution sources of gomti river (india) using multivariate statistical techniques-A case study. Anal. Chim. Acta 2005, 538, 355-374. [CrossRef]

14. Ogwueleka, T.C. Use of multivariate statistical techniques for the evaluation of temporal and spatial variations in water quality of the Kaduna River, Nigeria. Environ. Monit. Assess. 2015, 187, 137. [CrossRef] [PubMed]

15. Sheikhy Narany, T.; Ramli, M.F.; Aris, A.Z.; Sulaiman, W.N.; Fakharian, K. Spatiotemporal variation of groundwater quality using integrated multivariate statistical and geostatistical approaches in Amol-Babol Plain, Iran. Environ. Monit. Assess. 2014, 186, 5797-5815. [CrossRef] [PubMed] 
16. Mustapha, A.; Aris, A.Z.; Juahir, H.; Ramli, M.F.; Kura, N.U. River water quality assessment using environmentric techniques: Case study of Jakara River Basin. Environ. Sci. Pollut. Res. Int. 2013, 20, 5630-5644. [CrossRef] [PubMed]

17. Sharma, A.; Bora, C.R.; Shukla, V. Evaluation of seasonal changes in physico-chemical and bacteriological characteristics of water from the Narmada River (India) using multivariate analysis. Nat. Resour. Res. 2013, 22, 283-296. [CrossRef]

18. Gatica, E.A.; Almeida, C.A.; Mallea, M.A.; Del Corigliano, M.C.; Gonzalez, P. Water quality assessment, by statistical analysis, on rural and urban areas of Chocancharava River (Río Cuarto), Córdoba, Argentina. Environ. Monit. Assess. 2012, 184, 7257-7274. [CrossRef] [PubMed]

19. Chen, Y.; Zhao, K.; Wu, Y.; Gao, S.; Cao, W.; Bo, Y.; Shang, Z.; Wu, J.; Zhou, F. Spatio-temporal patterns and source identification of water pollution in Lake Taihu (China). Water 2016, 8, 86. [CrossRef]

20. Qin, B.; Xu, P.; Wu, Q.; Luo, L.; Zhang, Y. Environmental issues of Lake Taihu, China. Hydrobiologia 2007, 581, 3-14. [CrossRef]

21. Ackerman, D.; Weisberg, S.B. Relationship between rainfall and beach bacterial concentrations on Santa Monica Bay beaches. J. Water Health 2003, 1, 85-89. [PubMed]

22. Wang, F.-E.; Tian, P.; Yu, J.; Lao, G.-M.; Shi, T.-C. Variations in pollutant fluxes of rivers surrounding Taihu Lake in Zhejiang Province in 2008. Phys. Chem. Earth Parts A/B/C 2011, 36, 366-371. [CrossRef]

23. Du, C.; Li, Y.; Wang, Q.; Liu, G.; Zheng, Z.; Mu, M.; Li, Y. Tempo-spatial dynamics of water quality and its response to river flow in estuary of Taihu Lake based on GOCI imagery. Environ. Sci. Pollut. Res. Int. 2017, 24, 28079-28101. [CrossRef] [PubMed]

24. Xu, S.; Huang, B.; Wei, Z.B.; Luo, J.; Miao, A.J.; Yang, L.Y. Seasonal variation of phytoplankton nutrient limitation in Lake Taihu, China: A monthly study from year 2011 to 2012. Ecotoxicol. Environ. Saf. 2013, 94, 190-196. [CrossRef] [PubMed]

25. Liu, J.; Liang, X.; Yang, J.; Ye, Y.; Su, M.; Nie, Z.; Chen, Y. Size distribution and composition of phosphorus in the East Tiao River, China: The significant role of colloids. J. Environ. Monit. 2011, 13, 2844-2850. [CrossRef] [PubMed]

26. Zhang, Y.; Shi, K.; Zhou, Y.; Liu, X.; Qin, B. Monitoring the river plume induced by heavy rainfall events in large, shallow, Lake Taihu using modis $250 \mathrm{~m}$ imagery. Remote Sens. Environ. 2016, 173, 109-121. [CrossRef]

27. Wang, X.-L.; Lu, Y.-L.; Han, J.-Y.; He, G.-Z.; Wang, T.-Y. Identification of anthropogenic influences on water quality of rivers in Taihu watershed. J. Environ. Sci. 2007, 19, 475-481. [CrossRef]

28. Hagedorn, C.; Liang, X. Current and future trends in fecal source tracking and deployment in the Lake Taihu region of China. Phys. Chem. Earth 2011, 36, 352-359. [CrossRef]

29. Lv, H.; Xu, Y.; Han, L.; Zhou, F. Scale-dependence effects of landscape on seasonal water quality in Xitiaoxi catchment of Taihu Basin, China. Water Sci. Technol. 2015, 71, 59-66. [CrossRef] [PubMed]

30. Tang, X.; Ullah, N.; Yu, C.; Qin, Z.; Huang, R.; Zhu, X.; Shen, C.; Chen, Y. Chemical and bioassay analysis of estrogen pollution in the surface water of the Tiaoxi river, the source river for Taihu Lake. Bull. Environ. Contam. Toxicol. 2012, 89, 816-819. [CrossRef] [PubMed]

31. Zheng, J.; Gao, R.; Wei, Y.; Chen, T.; Fan, J.; Zhou, Z.; Makimilua, T.B.; Jiao, Y.; Chen, H. High-throughput profiling and analysis of antibiotic resistance genes in east Tiaoxi river, China. Environ. Pollut. 2017, 230, 648-654. [CrossRef] [PubMed]

32. Ministry of Environmental Protection of the People's Republic of China (MEP). Environmental Quality Standards for Surface Water; GB 3838-2002; MEP: Beijing, China, 2002.

33. Wang, J.; Soininen, J.; Zhang, Y.; Wang, B.; Yang, X.; Shen, J. Contrasting patterns in elevational diversity between microorganisms and macroorganisms. J. Biogeogr. 2011, 38, 595-603. [CrossRef]

34. APHA. Standard Methods for the Examination of Water and Wastewater, 21st ed.; American Public Health Association: Washington, DC, USA, 2005.

35. Reasoner, D.J.; Geldreich, E.E. A new medium for the enumeration and subculture of bacteria from potable water. Appl. Environ. Microbiol. 1985, 49, 1-7. [PubMed]

36. Baylis, C.L.; Patrick, M. Comparison of a Range of Chromogenic Media for Enumeration of Total Coliforms And E. coli in Foods; Leatherhead International Technical Notes, No. 135; Leatherhead Food Research Association: Epsom, UK, 1999. 
37. Kazi, T.G.; Arain, M.B.; Jamali, M.K.; Jalbani, N.; Afridi, H.I.; Sarfraz, R.A.; Baig, J.A.; Shah, A.Q. Assessment of water quality of polluted lake using multivariate statistical techniques: A case study. Ecotoxicol. Environ. Saf. 2009, 72, 301-309. [CrossRef] [PubMed]

38. Alberto, W.D.; Pilar, D.M.D.; Valeria, A.; Fabiana, P.S.; Cecilia, H.A.; Angeles, B.M.D.L. Pattern recognition techniques for the evaluation of spatial and temporal variations in water quality. A case study: Suquia river basin (Cordoba-Argentina). Water Res. 2001, 35, 2881-2894. [CrossRef]

39. Singh, K.P.; Malik, A.; Mohan, D.; Sinha, S. Multivariate statistical techniques for the evaluation of spatial and temporal variations in water quality of Gomti River (India) —A case study. Water Res. 2004, 38, 3980-3992. [CrossRef] [PubMed]

40. Helena, B.; Pardom, R.; Vega, M.; Barrado, E.; Fernandez, J.M.; Fernandez, L. Temporal evolution of groundwater composition in an alluvial aquifer (Pisuerga River, Spain) by principal component analysis. Water Res. 2000, 34, 807-816. [CrossRef]

41. Abdul-Wahab, S.A.; Bakheit, C.S.; Al-Alawi, S.M. Principal component and multiple regression analysis in modelling of ground-level ozone and factors affecting its concentrations. Environ. Model Softw. 2005, 20, 1263-1271. [CrossRef]

42. Chapman, D. Water Quality Assessments-A Guide to Use of Biota, Sediments and Water in Environmental Monitoring; Cambridge University Press: Cambridge, UK, 1996.

43. Pearce, G.R.; Ramzan Chaudhry, M.; Ghulam, S. A Simple Methodology for Water Quality Monitoring; Department for International Development, HR Wallingford: Wallingford, UK, 1999.

44. United States Environmental Protection Agency (USEPA). Available online: http://water.epa.gov/type/rsl/ monitoring/vms511.cfm (accessed on 17 January 2017).

45. United States Environmental Protection Agency (USEPA). Total Nitrogen; USEPA Office of Water Office of Science and Technology: Washington, DC, USA, 2013.

46. Farhadinejad, T.; Khakzad, A.; Jafari, M.; Shoaee, Z.; Khosrotehrani, K.; Nobari, R.; Shahrokhi, V. The study of environmental effects of chemical fertilizers and domestic sewage on water quality of Taft region, Central Iran. Arab. J. Geosci. 2012, 7, 221-229. [CrossRef]

47. Yan, C.A.; Zhang, W.; Zhang, Z.; Liu, Y.; Deng, C.; Nie, N. Assessment of water quality and identification of polluted risky regions based on field observations \& GIS in the honghe river watershed, China. PLoS ONE 2015, 10, e0119130. [CrossRef]

48. Lucassen, E.C.H.E.T.; Smolders, A.J.P.; Vander Salm, A.L.; Roelofs, J.G.M. High groundwater nitrate concentrations inhibit eutrophication of sulphate-rich freshwater Wetlands. Biogeochemistry 2004, 67, 249-267. [CrossRef]

49. Fewtrell, L. Drinking-water nitrate, methemoglobinemia, and global burden of disease: A discussion. Environ. Health Perspect. 2004, 112, 1371-1374. [CrossRef] [PubMed]

50. United States Environmental Protection Agency (USEPA). Aquatic Life Ambient Water Quality Criteria for Ammonia-Freshwater; United States Environmental Protection Agency Office of Water Office of Science and Technology: Washington, DC, USA, 2013.

51. Xu, H.; Yang, L.-Z.; Zhao, G.-M.; Jiao, J.-G.; Yin, S.-X.; Liu, Z.-P. Anthropogenic impact on surface water quality in Taihu Lake region, China. Pedosphere 2009, 19, 765-778. [CrossRef]

52. Shock, C.C.; Pratt, K. Phosphorus effects on surface water quality and phosphorus TMDL development. In Proceedings of the Western Nutrient Management Conference, Salt Lake City, UT, USA, 6-7 March 2003; pp. 211-220.

53. Xu, H.; Paerl, H.W.; Qin, B.; Zhu, G.; Gaoa, G. Nitrogen and phosphorus inputs control phytoplankton growth in eutrophic Lake Taihu, China. Limnol. Oceanogr. 2010, 55, 420-432. [CrossRef]

54. U.S. Congress. Beaches Environmental Assessment and Coastal Health Act (BEACH Act). Stat. 870-877, Public Law 106-284. In Proceedings of the 106th U.S. Congress, Washington, DC, USA, 2000.

55. Pisciotta, J.M.; Rath, D.F.; Stanek, P.A.; Flanery, D.M.; Harwood, V.J. Marine bacteria cause false-positive results in the colilert-18 rapid identification test for escherichia coli in florida waters. Appl. Environ. Microbiol. 2002, 68, 539-544. [CrossRef] [PubMed]

56. Schriewer, A.; Miller, W.A.; Byrne, B.A.; Miller, M.A.; Oates, S.; Conrad, P.A.; Hardin, D.; Yang, H.H.; Chouicha, N.; Melli, A.; et al. Presence of bacteroidales as a predictor of pathogens in surface waters of the Central California Coast. Appl. Environ. Microbiol. 2010, 76, 5802-5814. [CrossRef] [PubMed] 
57. Haller, L.; Amedegnato, E.; Poté, J.; Wildi, W. Influence of freshwater sediment characteristics on persistence of fecal indicator bacteria. Water Air Soil Pollut. 2009, 203, 217-227. [CrossRef]

58. Muirhead, R.W.; Davies-Colley, R.J.; Donnison, A.M.; Nagels, J.W. Faecal bacteria yields in artificial flood events: Quantifying in-stream stores. Water Res. 2004, 38, 1215-1224. [CrossRef] [PubMed]

59. Heaney, C.D.; Myers, K.; Wing, S.; Hall, D.; Baron, D.; Stewart, J.R. Source tracking swine fecal waste in surface water proximal to swine concentrated animal feeding operations. Sci. Total Environ. 2015, 511, 676-683. [CrossRef] [PubMed]

60. Vieira, J.S.; Pires, J.C.M.; Martins, F.G.; Vilar, V.J.P.; Boaventura, R.A.R.; Botelho, C.M.S. Surface water quality assessment of Lis river using multivariate statistical methods. Water Air Soil Pollut. 2012, 223, 5549-5561. [CrossRef]

61. Pejman, A.H.; Nabi Bidhendi, G.R.; Karbassi, A.R.; Mehrdadi, N.; Bidhendi, M.E. Evaluation of spatial and seasonal variations in surface water quality using multivariate statistical techniques. Int. J. Environ. Sci. Technol. 2009, 6, 467-476. [CrossRef]

62. Phung, D.; Huang, C.; Rutherford, S.; Dwirahmadi, F.; Chu, C.; Wang, X.; Nguyen, M.; Nguyen, N.H.; Do, C.M.; Nguyen, T.H.; et al. Temporal and spatial assessment of river surface water quality using multivariate statistical techniques: A study in Can Tho City, a Mekong Delta area, Vietnam. Environ. Monit. Assess. 2015, 187, 229. [CrossRef] [PubMed]

63. Liu, C.-W.; Lin, K.-H.; Kuo, Y.-M. Application of factor analysis in the assessment of groundwater quality in a blackfoot disease area in Taiwan. Sci. Total Environ. 2003, 313, 77-89. [CrossRef]

64. Ruzdjak, A.M.; Ruzdjak, D. Evaluation of river water quality variations using multivariate statistical techniques: Sava river (croatia): A case study. Environ. Monit. Assess. 2015, 187, 215. [CrossRef] [PubMed]

(C) 2018 by the authors. Licensee MDPI, Basel, Switzerland. This article is an open access article distributed under the terms and conditions of the Creative Commons Attribution (CC BY) license (http:/ / creativecommons.org/licenses/by/4.0/). 